\title{
Class disparities and social inequalities
}

Class is back - class inequalities now feature centrally in multiple media, are core to campaigns and protest movements, and are a part of everyday conversation. Mitigating the adverse effects of class again plays a key role in policy formation and formal politics. James Pattison and Tracey Warren consider how far the UK's approach meets or falls below the types and levels of action that any liberal democracy requires.

\section{How should a genuinely democratic society promote greater class equality?}

Public policy should focus on addressing and mitigating the structural causes of social and occupational class inequalities, rather than taking refuge in individualised explanations.

Positive policies are needed to ensure that working-class people have an equal political voice.

Class is not yet a protected characteristic covered by the UK's equality legislation it should become the tenth such characteristic.

This stance needs to be backed up by policies to curb the expression of discriminatory views and other 'symbolic violence' inflicted on working-class people and used to stigmatise them as a group and the places where they live.

Public policies need to guarantee quality working lives for the working classes providing a minimum floor to job quality so as to promote decent work. This floor should cover wages, work-time, job security, worker representation and support for a decent work-life balance.

Taxation and benefits policies should ensure a minimum income standard via transfers, and include a progressive system of taxation (with a levy on wealth).

In any capitalist society, social housing policies are an inescapable part of mitigating class inequalities. Meaningful reinvestment is needed in social housing - along with the democratisation of housing management and policy so as to fully include working-class residents in managing their own accommodation and neighbourhoods. 
Class is a highly charged word which politicians, media commentators and others are often reluctant to use. Not so long ago now, some serious social scientists doubted the societal importance of class. Even when it was not denied, classed inequality was often discussed implicitly - as disparities of 'income', or via euphemistic or distracting ideas of 'poverty' and 'the poor'; 'economic disadvantage'; or socio-economic 'deprivation'.

Yet now class is increasingly recognised as having enduring significance for describing the distribution of advantage and disadvantage. A focus on injustice, inequality and value is fundamental to class-based analysis. Economic inequalities are core to how class shapes people's everyday lives and life-chances. Yet class inequalities are also about how we relate to others and to ourselves - and class 'intersects' with other social divisions such as gender, ethnicity and age.

\section{Recent developments}

The highly class-privileged - the upper class, the elite, the 'super rich' - have attracted attention in the face of deep economic inequalities post-crisis. High incomes were defined by HMRC as a minimum gross pay of $£ 162,000$ in $2014-15$, but much executive pay in the private sector is far greater. In addition, inequalities of wealth far outstrip those of income in the UK. The system of taxation in the UK has not kept up with the 'meteoric rise' in the amount of wealth held by 'the 1\%'. For 2014 data the Resolution Foundation estimated that 'the 1\%' owned £11 trillion in financial, private pension, property and physical wealth (14\% of the nation's assets).

Very high pay levels and the wealth held by 'the 1\%' led to the birth of the Occupy protest movement in 2011 to work against inequality and towards improved democracy. Their slogan 'We are the 99\%' promotes a unity of the many against the privileged few. Protest movements against severe inequalities mirror influential academic research into the extremes of class inequalities and the multiple negative impacts of intense inequality on society, by such writers as Kate Pickett and Richard Wilkinson, Danny Dorling, John Hills, Thomas Piketty and Guy Standing.

The middle class was forecast (incorrectly) to fare most poorly in a projected 'first middleclass recession' from 2008 on. It also appeared, later, in the 'squeezed middle' narratives of the Labour Party under Ed Miliband - reflecting the political attractiveness of this more 'striving' or 'aspirational' labelling. (Yet the same 'squeezed' group was identified by some observers as contributing to the Brexit Leave momentum.)

By 2016, however, the working class were central too to the discourses about the 'just about managing' and 'ordinary working families' in the 2016 Brexit campaign. In her first statement as Prime Minister, Theresa May said:

'If you're from an ordinary working-class family, life is much harder than many people in Westminster realise [.. You have a job but you don't always have job security. You have your own home, but you worry about paying a mortgage. You can just about manage but you worry about the cost of living and getting your kids into a good school. If you're one of those families, if you're just managing, I want to address you directly'. (Prime Minister's Office, 2016). 
Questions about class disparities in the UK were boosted post-recession, and in the leadup to and aftermath of the $2016 \mathrm{EU}$ referendum. Again, the working class featured implicitly, as the vote outcome was ascribed to the impacts of austerity and globalisation on 'left behind communities'. And some explicit critiques were made of the class background of Brexit voters.

Mounting concerns with a very heavy concentration of wealth and privilege even made their way into the Conservative election manifesto in 2017, where a vision was set out of 'A fairer Britain that works for everyone, not just a privileged few' (p.5). In its expressed aim to make Britain 'the world's great meritocracy', the May government also stated (although again with class left implicit): 'The greatest injustice in Britain today is that your life is largely determined not by your efforts and talents but by where you come from, who your parents are and what schools you attend,' (p.49).

One of the more subtle ways that class disparagement works is via the vocabularies used. Outside the careful phrasing of manifestos, class-disadvantaged groups are characteristically depicted at best as the 'deprived' and 'under-privileged'. In everyday language, talk of hipsters and chavs, or toffs and hoodies all contain classed assumptions. The names associated with those at the bottom of society are often particularly disparaging and morally loaded, 'producing' the working class as 'disgusting subjects'.

\section{The class structure of the UK}

The numbers of well-paying industrial manual jobs have fallen greatly in Britain over time, a drop fuelled by contracting manufacturing industries. There has been a long-term expansion of people working in services, with manual jobs concentrated especially in such low-paid sectors as retail, hospitality and catering, as Figure 1 shows.

Figure 1: The official view of occupational classes in 2017, and their gender balance

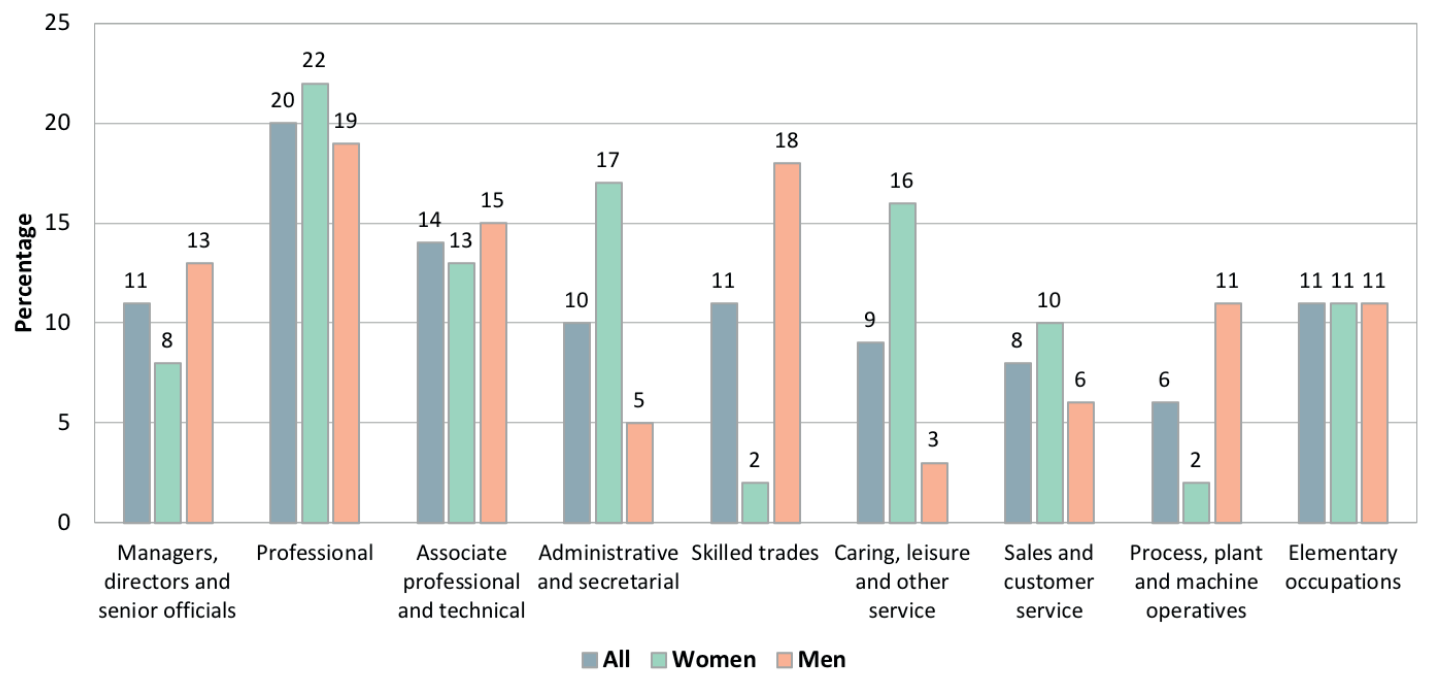

Source: Quarterly Labour Force Survey, April-June 2017 
Nearly a third of the working population are officially categorised as professionals or managers (the two leftmost groupings in Figure 1), while including the 'associate professional and technical' group would place almost half of the population in an upper-/ middle-class group. Among the remaining 'working-class' groups, women work especially in administrative/secretarial and caring/leisure jobs, while men still overwhelmingly predominate in the 'skilled trades' and 'process, plant and machinery operatives'.

The 2011 'Great British Class Survey' (involving the BBC) moved beyond the emphasis on occupation as a signifier of social class and collected information on the economic, social and cultural capital of 160,000 people. The authors concluded that traditional depictions of class (working, middle, upper) were out of date, and proposed instead a seven-class schema influenced far more equally by people's occupations, their wealth, social contacts and their 'cultural capital' - shown in Figure 2.

\section{Figure 2: The 'Great British Class Survey’ categories and their sizes in 2011}

\begin{tabular}{|c|c|c|}
\hline $\begin{array}{l}\text { GBC } \\
\text { categories }\end{array}$ & $\begin{array}{l}\% \text { of UK } \\
\text { population }\end{array}$ & Brief description \\
\hline Elite & 6 & $\begin{array}{l}\text { Very high economic capital (especially savings), high social } \\
\text { capital, very high highbrow cultural capital. }\end{array}$ \\
\hline $\begin{array}{l}\text { Established } \\
\text { middle class }\end{array}$ & 25 & $\begin{array}{l}\text { High economic capital, high status of mean contacts, high } \\
\text { highbrow and emerging cultural capital. }\end{array}$ \\
\hline $\begin{array}{l}\text { Technical } \\
\text { middle class }\end{array}$ & 6 & $\begin{array}{l}\text { High economic capital, very high mean social contacts, but } \\
\text { relatively few contacts reported, moderate cultural capital. }\end{array}$ \\
\hline $\begin{array}{l}\text { New affluent } \\
\text { workers }\end{array}$ & 15 & $\begin{array}{l}\text { Moderately good economic capital, moderately poor mean } \\
\text { score of social contacts, though high range, moderate } \\
\text { highbrow but good emerging cultural capital. }\end{array}$ \\
\hline $\begin{array}{l}\text { Traditional } \\
\text { working class }\end{array}$ & 14 & $\begin{array}{l}\text { Moderately poor economic capital, though with reasonable } \\
\text { house price, few social contacts, low highbrow and } \\
\text { emerging cultural capital. }\end{array}$ \\
\hline $\begin{array}{l}\text { Emergent } \\
\text { service } \\
\text { workers }\end{array}$ & 19 & $\begin{array}{l}\text { Moderately poor economic capital, though with reasonable } \\
\text { household income, moderate social contacts, high emerging } \\
\text { (but low highbrow) cultural capital. }\end{array}$ \\
\hline Precariat & 15 & $\begin{array}{l}\text { Poor economic capital, and the lowest scores on every other } \\
\text { criterion. }\end{array}$ \\
\hline
\end{tabular}

Source: Savage et al (2012)

The elite and established middle class in Figure 2 form almost a third of UK respondents, with a technical middle class and new affluent workers constituting a further fifth of the population in the middle. Working-class people divide relatively evenly between a traditional working class (often owning their homes though), a group of emergent service workers (some with high cultural capital), and a 'precariat' whose economic and social position is fragile. 
Despite the fall in (manual) jobs traditionally seen as 'working class', successive British Social Attitudes (BSA) surveys found that 60-63\% of British respondents see themselves as 'working class', with the remaining group (just under 40\%) describing themselves as 'middle class'. There is hardly any variation from one year to the next. And between 2005 and 2015 people became more aware of class differences:

'We find Britain divided along class lines. Nearly 8 in 10 of us think that the divide between social classes is wide or very wide. We are less likely now to think it possible to move between social classes than in the past'. (BSA, 2016).

\title{
Strengths, Weaknesses, Opportunities, Threats (SWOT) analysis
}

\section{Current strengths}

\section{Current weaknesses}

\author{
In terms of working lives
}

Unemployment in mid-2018 stood at $4 \%$, its lowest level since 1975 (ONS August 2018). Positive consequences include reduced class gaps in labour force participation rates, and perhaps increases in levels of wages and income.

The UK has a national minimum wage which rose to $£ 7.83$ per hour in 2018 (for people over 25), almost matching the level in Germany. The NMW is set to increase substantially leading up to 2020 . It will henceforward be officially called the National Living Wage.

Free childcare expanded to 30 hours a week in September 2017 (see below). The change can assist more women into paid work, although trials suggested the entitlement was being taking up more by middle-class parents.
Concerns around deep class inequalities have been accentuated by the declining quality of new service jobs, especially in terms of worsening (or vanishing) job security, the expansion of zero-hours contracts and the so-called 'gig economy' (see Chapter 7.4). Low official unemployment rates partly reflect a growth in work-time underemployment (where low paid workers want but cannot get more paid hours - see below) and in marginal self-employment.

The NMW is very low for younger workers - dropping to only £5.60 an hour for 18-20 year olds. Real earnings in 2018 are lower than before the recession hit. The extent of in-work poverty is testament to the lowpaying jobs held by many of the working class.

Class inequalities persist in the support available for working parents. Given scarce supply, the extension of free childcare could deepen rather than reduce class inequalities in childcare use. Problems from the provider perspective (such as rising delivery costs, falling profits, difficulties in staff recruitment and limited space in venues for expanded numbers) also raise concerns about whether the policy changes are sustainable. 


\section{Current weaknesses}

In terms of living standards

According to the Office for Budget

Responsibility (2017, p.5), the UK government spends around £486bn (26\% of GDP, 201516) on the welfare state.
Systematic cutbacks in public spending continued into 2017 and some are budgeted to continue throughout the life of this parliament. In 2017 the Institute of Fiscal Studies noted how 'terrible' economic growth since 2008 created 'big problems' for the finances of both households and government.

Since April 2017, the child tax element paid to new claimants of the 'Universal Credit' scheme has applied only for the first two children in a household. This is predicted to cut the benefits of 515,000 larger families by 2020.

Extending the conditionality of welfare payments, and the use of punitive benefit sanctions against people whose behaviour is judged non-compliant with increasingly prescriptive benefits rules, have adversely impacted the lives of hundreds of thousands of poor people - both those who are out of work (often because of disabilities) and those in low-paid and insecure jobs.

Stark class inequalities in living standards persist in the UK, as signalled by the huge gaps in income and wealth levels between 'the $1 \%$ ' and the majority.

In terms of housing provision

The Conservative Party's 2017 manifesto promised reinvestment in 'short-term' social housing. Some small increases in funding followed. In 2018, a consultation paper on the future of social housing was launched by the government.
More long-term and larger-scale solutions are needed to combat the current lack of affordable and social housing. 


\section{Current strengths \\ One substantial disincentive to well-off people or companies purchasing multiple 'buy to let' properties was introduced in 2016 with a Stamp Duty surcharge.}

\section{Current weaknesses}

Housing in Britain is still seen as a commodity rather than a basic right. 'Gentrification' in cities has especially reduced the supply of low-cost housing in convenient locations for getting to jobs. The expansion of 'buy to let' housing has raised all house prices and meant more households must cope with the expense and insecurity of private renting. In some cities and locations Airbnb and similar schemes have reduced the supply of rental housing for local people.

The pursuit of deregulation and removal of 'red-tape' in housing has had high human costs, as witnessed by the spiralling of multi-occupation and the shocking lapses in securing basic safety in social housing revealed by the Grenfell Tower catastrophe.

In terms of representations of class

There was a small increase in the numbers of MPs from less privileged backgrounds at the 2017 general election. Fewer MPs than before came from conspicuously privileged backgrounds, and there was the lowest proportion of privately educated MPs on record (29\%).

There is some evidence of softening public attitudes towards benefit claimants.
The dominant media and political representations of working-class people, and of the places where they live, remain disparaging. In particular, structural or systematic inequalities are normally presented as the consequences of individual failings. Both the political and media elites (including the BBC) continue to be dominated by people who are themselves drawn from elite-class backgrounds.

The negative portrayal of benefits claimants, especially in the right-wing press disables working-class people in politics, legitimises austerity and deepens class inequality. 
Future opportunities

\section{Future threats}

In terms of working lives

The government-appointed Taylor Review of modern working practices made clear that the quality of jobs is a key area for action.

A 'real Living Wage' campaign has sought to persuade employers to voluntarily pay workers (aged 18 and older) a minimum of $£ 8.75$ an hour (or £10.20 in London, where living costs are greater). Its spread and success has ramifications for narrowing the wage gap in those firms.

The rigid $1 \%$ cap on public sector wage rises (affecting nurses, teachers and civil servants from 2012 to early 2018) attracted mounting protests, and from 2018 was scheduled to (gradually) end.
Exiting the EU may become a serious threat to the quantity and quality of jobs in the UK if rights and entitlements around work guaranteed in EU law are not transposed into UK law, or are watered down in the transition.

Because it is a voluntary and non-statutory approach, only a minority of employers seem likely to sign up to a 'real Living Wage'.
Long-deferred public sector pay rises must all come out of existing government sector budgets. This inevitable 'catch-up' surge could squeeze finances further, or create pressures for compensating reductions in headcounts in the public sector with its generally better working conditions and stillstrong trade unions.

\section{In terms of living standards}

Campaigns have grown to establish an unconditional 'Basic Income', which advocates claim can provide a safety net for all classes - and buttress democracy by reducing state surveillance of behaviours.
Weak economic growth and cuts to welfare are predicted to power the biggest rise in inequality by 2020-21 for the last four decades (see below). Already planned cuts to benefits will impact more on low-income households.

Cuts to social care budgets signal threats to the most vulnerable in society, including those that require care and caregivers.

In terms of housing provision

Building on campaigns such as SHOUT - the campaign for social housing - may help to reverse the disinvestment in social housing over the last 30 years.
Further gentrification continues to threaten to displace the working classes - who may be priced out of more desirable areas, particularly in central London. 


\section{Future opportunities}

Proposals to reintroduce local rent caps ('rent controls') in areas of high housing stress have been aired by the Labour leader, Jeremy Corbyn. Widely used in other countries, such caps might not only keep rising costs in check (so making renting from private landlords more affordable), but also help to lower house prices.

\section{Future threats}

Ministers have recognised that benefits flowing via tenants to private landlords may just raise local rent levels. But they have not moved towards controlling rents, instead developing proposals for controlling the amount of rent that is eligible for housing benefits across local areas. This might have some weak effects in keeping local rents down. Alternatively, it may just further impoverish people living on the now lowered benefits.

A greater democratisation of social housing management and policy may follow the Grenfell Inquiry report, where Kensington and Chelsea's supposed 'tenant management organisation' in fact gave residents little influence.

\section{In terms of representations of class}

Class upbringing still lies outside the list of 'protected characteristics' that are covered by the Equality Act 2010 (which include sex, race, age, sexual orientation). Current equality legislation does not prevent employers, education providers, government departments and so on from discriminating, harassing or victimising someone on the basis of their social class. This is a relatively easy thing to change, and doing so could counteract representations of workingclass people and areas that do so much to intensify the effects of inequalities.

Achieving further increases in MPs from less privileged backgrounds could rebalance political representation.

More positive representations of workingclass life in the media and public sphere could counteract key forces worsening the experiences of a classed society. Achieving more diversity in key media professional occupations might also help.
The outcome of the EU referendum has been (inaccurately) attributed to a problematic 'white' working class, reinforcing and potentially intensifying already existing social divisions along axes of class, ethnicity and migration status. 


\section{Living standards stress and benefits changes}

Working-class lives are marked by far more strained living conditions than other classes. Their low and middle incomes are accompanied by weak financial safety nets, if any. In $2016,64 \%$ of people living in low- and middle-income households reported having less than $£ 1,500$ in savings. The same 2017 study found that in 2014 , the lowest $15 \%$ of people on a wealth scale either owned no assets at all or were in debt. Working-class people especially scrape by, reporting relentless and demoralising everyday worries about spending and accumulating debts - such as some parents caring for children whilst unable to heat their homes or afford hot water. A 2016 estimate was that six million families were 'just about managing'. Financial problems grew so intense in the UK that the numbers of people using charitable food banks for essentials rocketed. Loan sharks offering highinterest loans proliferated, as did pawn shops offering high-interest loans in exchange for personal items.

The UK is committed to meeting the United Nation's (UN) 2030 'Sustainable Development Goals'. Target 10.1 is to: 'progressively achieve and sustain income growth of the bottom $40 \%$ of the population at a rate higher than the national average'. Yet research found that the incomes of the bottom 40\% of people were growing more slowly in 2016-17 than the higher $60 \%$. Median household income in 2015-16 was only 3.7\% higher than before the recession (2007-8), after adjusting for inflation, indicating only a 'glacially' slow growth over time. Another analysis estimated 'that typical incomes increased by just 0.9\% (after housing costs) in 2017-18. This is weak, representing less than half the average annual growth rate recorded between 1994 and 2007.'

Because recent levels of unemployment have been low, fewer people in Britain were without any earnings at all, and this has held income inequality down. A 'Minimum Income Standard' (MIS) for the UK, which reports on how much income households need to afford an acceptable minimum standard of living, also identified a steadying partly because of the introduction of the higher 'National Living Wage'. In 2017, the adequacy of incomes fell again, particularly for households with children, because of inflation and the freezing of benefits. Few families can reach this MIS with only one person working full-time on the national minimum wage. Projections to 2020-21 suggest that the biggest rise in inequality since the 1980s looms, powered by weak economic growth and by cuts to welfare for those with the lowest incomes.

The absolute poverty level is defined in the government's official measure as falling below $60 \%$ of median household income. Levels here changed little and showed about $22 \%$ of households living in poverty in 2015-16. Yet this lack of progress in reducing poverty is historically rare. Inflation rose sharply in 2017 while benefit cuts deepened, adding to the risks of more class-based financial hardship. The majority of those officially classified as 'poor' are not in households with no paid work at all: most live in a household where someone is in (low) paid work. According to the Child Poverty Action Group there were 4.1 million children living in poverty in 2016-17, amounting to $30 \%$ of all children in the country.

Poverty adversely impacts people's lives in manifold ways. For example, fully $50 \%$ of families in the bottom income quintile would like to take their children away on holiday for 
just one week a year, but cannot afford to. 'Fuel poverty' among low-income families has increased, testifying to life on a low income with rising bills and an inadequate everyday standard of living. Between April 2017 and March 2018, the Trussell Trust supplied nearly $1,333,000$ three-day emergency food supplies, a $13 \%$ increase on the previous year, with the three main reasons for lack of income being debt, benefit delays and changes in household circumstances.

Meanwhile the 'poverty premium' consists of the 'additional costs [that] low-income households pay for goods and services compared to those on higher incomes'. This amounts to an estimated extra $£ 490$ per household per year, including the extra costs of living in economically disadvantaged areas (for example, paying an extra $£ 74$ for car insurance and an additional $£ 227$ in grocery bills in locations poorly served by supermarkets).

\section{Benefit cuts and changes}

'Reforms' in how state benefits are paid have also worsened working people's lives. The Universal Credit (UC) was designed to replace six working-age benefits. It targets both those out of work and in paid work on a low income and with few savings, estimated to be eight million households. UC was devised with multiple aims: to simplify the benefits system, to make work pay, to increase take up of some benefits, and to reduce fraud and error. Yet its implementation has set off many alarms. Numerous problems have been cited with inefficiencies in its delivery, delaying its full rollout until 2020.

Because benefits are now paid monthly, and in arrears, there are also serious concerns about how people can get by in the long period before a first UC payment (up to six weeks), with ramifications for those who are in a 'low-pay/no-pay' cycle caused by insecure jobs. Referrals for emergency food supplies grew higher in those areas where UC was rolled out (a 17\% average increase) compared to the national average of 7\%. Queries have also been raised about UC's imposition of monthly household budgeting on those lowincome households who operated weekly accounting before UC. This affects women most, who are commonly responsible for budgeting, shopping and feeding families.

More fundamentally, there are serious concerns with Universal Credit's underpinning assumptions, including a conditionality that is 'backed by an extensive tiered system of very harsh benefit sanctions and a new range of civil penalty fines'. For working-class people UC extends conditionality, and harsh sanctions, to low-paid workers in insecure jobs. The impact of benefit sanctions on people living with a disability or chronic illness has also attracted condemnation. Claimed evidence that sanctions increase employment rates for disabled people is far from conclusive. Overall, UC's founding assumptions are 'divorced from what we know' about life for those either in 'low-waged and often insecure employment' or on a low non-waged income.

Equally slated was the so-called bedroom tax, first implemented in 2013, portrayed by ministers as removing a subsidy for working-age social housing tenants deemed to have a spare bedroom (by $14 \%$ for one spare bedroom, $25 \%$ for two or more). A formal evaluation, commissioned by the Department for Work and Pensions in 2015, found that affected 
tenants were forced to cut back on essentials such as heating and food. Other research has shown mounting hardship and debt from the policy has adversely affected tenants' mental health, caring arrangements (especially for disabled people whose carers can no longer stay overnight), family relationships and community networks. It has also led to falls in children's performance in school linked to having less private space to study in circumstances of intensifying poverty.

\section{Changing working lives in a class society}

Although UK employment levels were high by mid-2018, the quality of jobs (rather than their quantity) is widely seen as a major UK problem. This issue is structured along class lines. The lead author of the Taylor Review into 'Employment practices in the modern economy' declared at its launch:

'Our national performance on the quantity of work is strong. But quantity alone is not enough for a thriving economy and fair society. We believe now is the time to complement that commitment to creating jobs with the goal of creating better jobs'. (Department for Business, Energy and Industrial Strategy 2017).

In 2017 real earnings were still lower than before the recession hit. Incomes for the bottom earners were supported by the national minimum wage (NMW), which has clearly not increased UK joblessness (as many critics on the right had predicted) and has improved the wages of those in lower-level occupations. The proportion of workers covered by the NMW grew higher in 2016 for workers without qualifications, with disabilities, for women, ethnic minorities, migrants, part-timers and workers in cleaning, hairdressing and hospitality (Low Pay Commission, 2016). In the 2017 general election both parties committed to raise NMW substantially by 2020 (to £8.75 an hour from the Conservatives, and £10 from Labour). The Low Pay Commission claimed that after the government rate was implemented then 'measured on a like-for-like basis, the UK will have one of the highest minimum wages in the world'.

Surveys show that job security was the job attribute rated as important by most UK respondents (92\% in 2015). But this was also the attribute they felt had become less attainable over time, with most disadvantage faced by those in the lowest social class. Job insecurity is known to be severe for workers in the so-called gig economy, perhaps most associated with driving and deliveries for Uber and Deliveroo. But it also applies in other occupations, such as writing, translating, coding and designing. Gig work is also associated with a range of other negative characteristics - notably very long, unregulated, and often anti-social hours; high intensity work; low pay; no employment protection, and no guarantee of work; and weak pensions arrangements.

Another markedly classed phenomenon has been work-time underemployment (WTU). This disproportionally affects workers in low-paid occupations, including part-timers who want but cannot find a full-time job, resulting in financial and psychological distress. To survive some participants can work in up to seven different jobs a week. WTU is linked with severe financial hardship, and was a growing cause of work-life imbalance for the working class. 
However, by 2016-17 'peak insecurity' may have passed: with expansion in full-time employment and falls in self-employment, part-time work and zero-hours contracts as employers found it harder to attract staff on poor conditions. Figure 3 shows that the proportion of part-timers working part-time involuntarily rose steeply from 2008 to 2012 , but then began to fall back almost as sharply. A number of legal judgments have expanded rights for 'gig' workers and policy actions to rebalance workers' lack of clout in negotiating with employers are promised, although how substantial any outcomes may be remains to be seen.

\section{Figure 3: The proportion of women and men part-timers working part-time involuntarily} because they could not find a full-time job

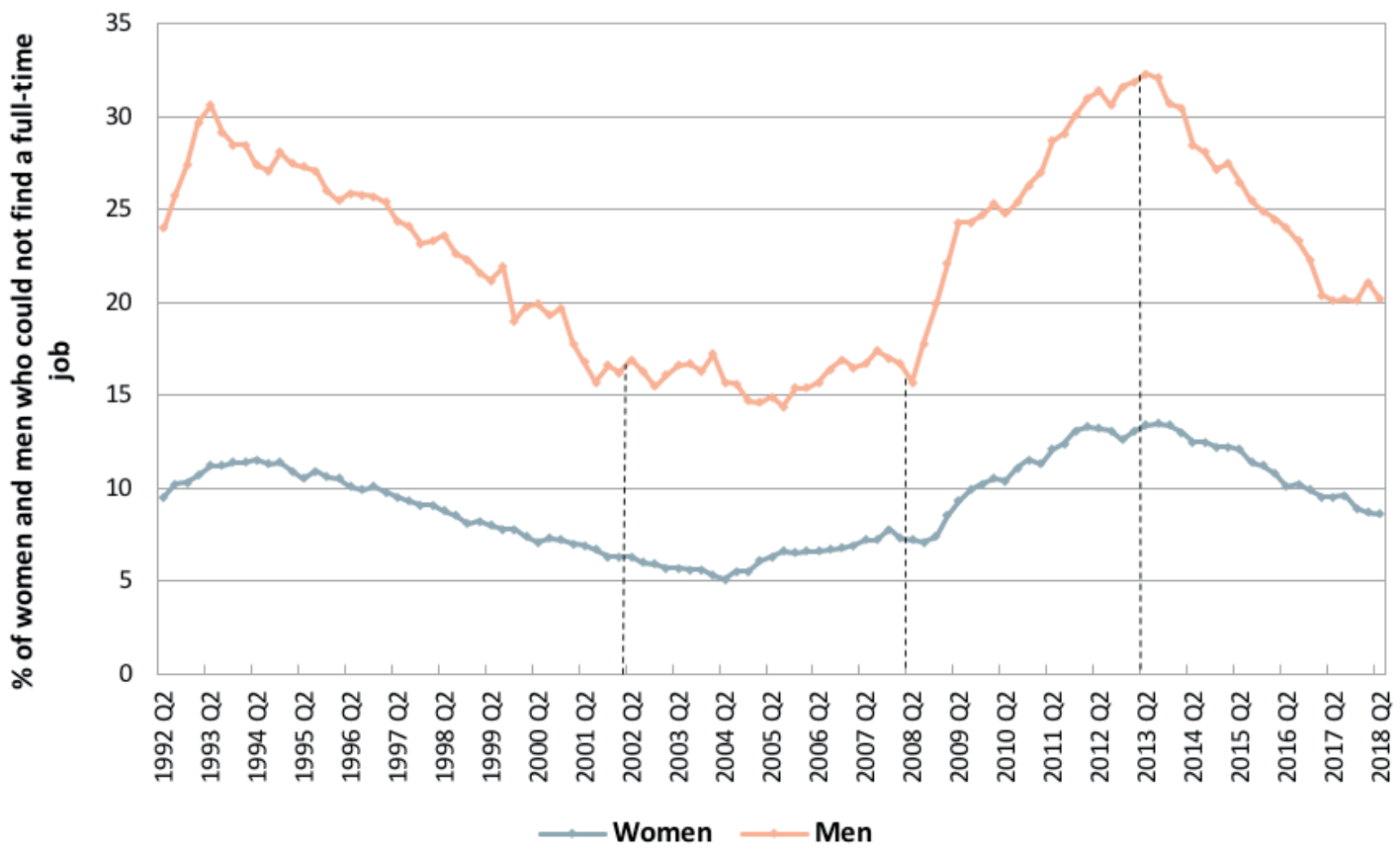

Source: Labour Force Survey, series ID: YCDC

\section{Parents and work}

There have been significant class gaps in the UK in how parents in paid work care for young children. Formal mechanisms (such as nurseries and childminders) are used far more by middle-class families, while informal care (often by grandparents) remained dominant for working-class working parents. Access to good, affordable and convenient childcare is a key way to support parents (especially mothers), into paid work, but formal childcare has been prohibitively expensive for many. Government initiatives have invested in early education and childcare with explicit motives to promote child development, narrow the gap in attainment 'between the most disadvantaged children and their better off peers', enable parents to work, and help with poverty reduction. 
From September 2017, working parents of children aged four became eligible to apply for 30 hours of funded, tax-free childcare per week for 38 weeks a year (doubling the 15 hours previously available in England). This scheme to 'support parents into work or to work more hours should they wish to do so' targets fathers and mothers earning or expecting to earn 'the equivalent to 16 hours at national minimum or living wage over the coming three months'. Parents earning more than $£ 100,000$ are not eligible. However, rather than favouring working-class families, trials of the scheme saw more uptake among middle-class families. Meanwhile, government statistics shows that many Sure Start centres, set up by the Labour government to support working-class pre-school children, closed (350 closed in England in 2010-16, while just eight new ones opened).

\section{How housing inequalities condition class}

Being able to secure a stable home in a particular area has huge implications for people's access to jobs, transport costs, and the environment in which they can afford to live. Yet greater inequalities in housing have opened up over recent years. At one extreme by 2017 there was a 32\% increase in homelessness case actions by English local authorities since 2009. At the other extreme the super-rich are buying up multiple properties, which are then left empty or underused whilst they appreciate in value for their already wealthy owners. Nowhere are these extremes of inequality more evident than in London, where the highest concentrations of wealth exist side by side with the highest concentrations of poverty. The conventional wisdom held that middle-class gentrifiers had the biggest impact on the class structure of London, but new evidence suggests that the global elites of many countries colonised central London, pushing less advantaged social classes towards its outskirts.

Growth in homeownership (once expected to be dominant in the Thatcher years) has ebbed away because of 'buy to let' purchasing, making private renting resurgent. After the 2008 financial crash middle-class home owners and investors experienced unexpected greater uncertainty, historically low interest rates and government and Bank of England financial policies propping up asset values. Large amounts of capital switched into "buy to let' housing, pushing prices out of reach of middle- and working-class people in many areas.

Conservative and coalition government policies responding to the 'housing crisis' focused mainly on subsidies to get first-time buyers on the housing ladder - despite evidence that tenure alone does not prevent poverty. (Over half of those living in poverty were homeowners.) Yet Thatcher's ideal of a property-owning democracy (boosting political stability and Tory voting) has dwindled for the lowest paid. And because social housing is scarce, this only leaves the private rental market, where cheap housing is insecure, expensive, and more likely to be of poor quality. The most vulnerable families are almost always renting, paying more and more to private landlords from meagre incomes, with a study by the Joseph Rowntree Foundation finding that 'the poorest fifth of the population [are] spending more than a third of their income on housing'. 
Past social housing policies in Britain recognised that much of the working class faced a chronic (perhaps perpetual) housing crisis. In 1979, 42\% of the UK population lived in council housing; today it is only $\mathbf{8 \%}$, chiefly because of the Thatcher government's $1980 \mathrm{~s}$ right-to-buy scheme. Although initially sold to sitting tenants, many former council houses are now in the hands of profit-seeking private landlords, who frequently do not maintain them to former standards, and charge significantly higher rents - mostly subsidised from public funds paying housing benefits. For instance, one study showed how a tenant on a former council estate was charged $£ 800$ per month by her private landlord for a unit that the council would charge $£ 360$ for.

This situation typifies the commodification of housing, where profit becomes the priority, housing prices are inflated and residents' needs are not met. Successive governments have squeezed spending on social housing, putting greater pressure on the need for affordable social housing. The 2017 Conservative Party manifesto included a promise to build a 'new generation of social housing', a pledge partly maintained at the Conservative conference in 2017. However, the manifesto also envisaged that these houses would return to the market after 10-15 years, to be sold privately via automatic right-to-buy policy.

\section{The Grenfell Tower disaster}

Many issues of class and its intersections with other inequalities were shockingly revealed by the Grenfell Tower disaster, where 72 people died in a fire on 14 June 2017 that spread rapidly throughout the council tower block. This occurred just a few streets away from some of London's wealthiest housing in Kensington and Chelsea (one of the UK's richest local authorities), dramatising the extreme inequalities within the capital.

It also raised acute questions of democracy, because the warning voices of concerned council tenants had been systematically ignored in implementing the cheapest possible refurbishment of blocks (see Chapter 5.3). Years of complaints from tenants' associations such as the Grenfell Action Group, highlighting the risk the building was at from disaster, were ignored out of hand by the Conservative local council. The cladding used during refurbishment was made from flammable material and had been chosen as a cost-cutting measure. Shifts towards ever more 'light touch' building and fire safety regulations were exposed as leaving not just Grenfell tenants but thousands of residents in hundreds of blocks across the country at terrible risk. The tragedy amply demonstrates how damaging and stigmatising representations of tenants have delegitimised and undermined workingclass voices, and so excluded them from central and local state concerns.

\section{Representations of the working class}

The ways that working-class people and the places they live are pictured and portrayed for the rest of society play a vital part in how class inequalities are controlled in the UK. The language of class may be absent from debates, but discussions of 'chavs', 'welfare', 'slums', 'council estates' and 'sink estates', and even the names of particular places, all contain classed assumptions. Sociologists argue that working-class people are seen by more powerful groups as unable to understand or usefully articulate their experiences. 
Sometimes working-class people are reproduced as 'disgusting subjects' through discriminatory descriptions of their bodies, clothes, behaviour and taste, for example tracksuited 'chavs'.

Pierre Bourdieu's concept of social distinction illustrates how middle-class taste is perceived as legitimate, and produced in opposition to a 'tasteless' working class, by extending it to argue that this also represents the working class as lacking value, as pathological and immoral. Bourdieu termed this struggle over culture 'symbolic violence', where domination is accepted tacitly and the dominated working class are not seen as having the right or ability to make legitimate judgements. It manifests as the ('natural') underrepresentation of working-class political opinion amidst multiple dominant political ideas generated by the middle and upper classes.

The popular 'poverty porn' TV sub-genre exemplifies these processes of social classification, symbolic violence and disgust. Beginning in 2013 programmes such as Benefits Street became a catalyst for public debate centred on questions of the welfare state. Poverty porn produces a symbolic divide between the 'worker' and the 'shirker' and encourages viewers to scorn the lifestyles of those featured in the programmes. Structural inequalities stemming from deindustrialisation and the precarity of the contemporary labour market are obscured, and instead poverty is represented as a lifestyle choice, with benefits claimants depicted as living it up at taxpayers' expense - further undermining welfare provisions. The 2017 BSA survey found evidence of softening attitudes towards benefits recipients, yet more people remain critical of benefit fraud than tax evasion.

Politicians and policy-makers often use the areas where the working classes live as signifiers for dangerous people and places. They use deprived areas as backdrops to make political claims that certain areas entrench poverty and disadvantage - for example, David Cameron's war on 'sink estates'. These depictions deflect attention away from the external forces that produce the conditions of existence for residents there, and instead stigmatise neighbourhoods further. Such messages can divide residents from each other, obstruct the potential for collective resistance to poor treatment, and often shape the future with regulations, investment and/or disinvestment in stigmatised territories.

A final illustration of adverse representation concerns the way that working-class people were blamed for the Brexit vote to leave the European Union, although the picture is actually far more complex than this. An instant narrative was coined portraying Leave voters as being from disadvantaged areas, 'left behind' by globalisation, particularly deindustrialised northern English towns (that is, implicitly white working-class communities) - an interpretation that deepened already existing social divisions along axes of class, ethnicity and migration status.

\section{Conclusions}

Class inequality and injustice in the UK in 2017 'intersects' with other social divisions with ramifications for how we understand the lives and life chances of different groups of working-class women and men. In a liberal democracy like the UK some control over class disparities and narrowing of class inequality gaps can only be achieved by establishing 
a firmer ceiling for the highly privileged (as housing market changes have shown), and by lifting the floor that supports the least class-advantaged in society (as the minimum wage and living wages have shown is feasible). In addition, making class a "protected characteristic' in future Equality Acts could actively combat discrimination and the stillprevalent stigmatisation of working-class people and neighbourhoods.

James Pattison is a postgraduate research student in the School of Sociology and Social Policy, University of Nottingham.

Tracey Warren is Professor of Sociology at the University of Nottingham. 